\title{
ЏУД ФОЛИ И СЈУ БРАЈДХЕД: ИЛУЗИЈЕ О ЖИВОТУ ВАН ДРУШТВЕНИХ ОКВИРА
}

Педагошки факултет, Сомбор

\begin{abstract}
Апстракт: Џуд и Сју, Хардијеви трагични љубавници, свако за себе, а онда и заједнички, сањају снове нетипичне за време и друштво у којем живе, крећу се изван задатих оквира свог друштвеног положаја, чиме покрећу механизам догађаја који ће довести до страшних жртава, а у коначном ишоду поново ће се успоставити претходно поремећена друштвена равнотежа у категоријама рода и класе. У том смислу, у овом раду покушавају се приказати узроци и последице веровања у илузије и тежњи да се избегну унапред одређене класне и родне улоге, као и узроци и последице самообмане којом се поново успоставља традиционални поредак, а који је, у коначном ишоду, само још једна илузија. Применом жираровског механизма миметичке жеље покушава се осветлити неминовност неуспеха измицања предодређеним улогама и снази друштвених конвенција у Неславном Цуду Томаса Хардија.
\end{abstract}

Кључне речи: Неславни Џуд, класа, род, илузија, самообмана, миметичка жеља, жртвена криза

Опште осећање које је владало Великом Британијом у деветнаестом веку било је осећање обавезе да се формира и промовише ригидан кодекс вредности, који је требало да одсликава не свет какав јесте, већ какав владајуће класе желе да буде. Тај кодекс, познат и под називом „Викторијански компромис“, заснивао се на осећању дужности и напорног рада, уважености, добротворном раду и филантропији, патријархалној породици и колонијализму. Свако одступање од устаљених форми потискивано је далеко на маргине друштва, било да је реч о самохраним мајкама, психички оболелим особама, пословно неуспешним синовима, слободним мислиоцима или сиротињи. Који год разлог био за излажење из оквира прописаних норми није био довољно добар да би, према мишљењу просечног Викторијанца, оправдао „безбожан“ статус неуспеха. У њиховој свести, и свести целокупног периода, бог је захтевао успех, заузврат дајући рајско насеље на оном свету, а неписаном заповести привилегије на овом. Позно викторијанско доба, у којем Хардијеви ликови живе своје суморне животе, најављује слом викторијанских вредности, сумњу у дотадашње строго ограничене, непроменљиве категорије, те рађа доба преиспитивања, тражења места под сунцем и улоге појединца у колективу, који је изгубио тло под ногама. 
Историјски тренутак у којем су се затекли јунаци Томаса Хардија ни за једно од њих није повољан. Џуд, препуштен самом себи од самог почетка свог живота, и поред интелектуалних способности и жеље за образовањем, остаје изван затвореног система школства који не нуди шансу младима попут њега, јер не може да прескочи ону материјалну препреку, према којој би му требало бар још петнаест година мукотрпног физичког рада, одрицања и штедње, како би уопште приступио полагању пријемног испита на неком од колеџа, чије је зидине, иронијом судбине, рестаурирао. Сју креће у живот са бољом образовном подлогом, али за оно чему она стреми то није довољно. Околина, па и она сама под тим утицајем, сматра њеном чудношћу то што је желела да чита и учи из књига које јој, као женској особи, не би биле доступне. Кроз њене односе са мушкарцима, најпре са једним крајстминстерским студентом, потом са Филотсоном и Џудом, покушава да заснује партнерство на нивоу вишем него што га нуди пука телесна привлачност или друштвени закон. Њен експеримент тзв. Нове жене завршава трагично.

Оквир - појам истовремено апстрактан и спутавајуће конкретан. Према Сари Кренгл (Crangle 2001), Томас Харди у Неславном Џуду (1964) обилато користи уоквирене слике (било да су то фотографије, прилике у прозорима, доврацима итд.) као одраз најистакнутије теме у роману: покушаја Џуда и Сју да превазиђу ограничења свог друштвеног статуса и конвенција. Кроз цео роман смењују се апстрактни и конкретни обриси оквира, граница, па чак се и једни претварају у друге и обрнуто, дајући овој повести у њеном расплету тон илузије, узалудности и безнађа.

Колико год границе и оквири водили у истом смеру, они се разликују за Сју и Џуда. Наиме, у самом роману, Сју се често појављује уоквирена физички, али и друштвено: први начин на који је Џуд види је путем њене фотографије, коју му даје његова тетка Друсила; касније је види кроз прозор радњице у којој је она радила као цртачица, а онда и у оквирима неколико прозора који представљају препреке за њихово зближавање. Нематеријалне оквире за Сју ствара друштво: јасно се намећу брачни оквири као једини могући услов за заједницу са мушкарцем; сама Сју чак два пута затвара себе наоко добровољним брачним заветом, тог другог пута изнуђеним трагичним последицама немилосрдне друштвене механике. Џуд, пак, измиче оквирима у самом роману: као дечак, не успева да види свој одраз у зденцу старог бунара; трговац га не препознаје са фотографије коју је Арабела, његова одбегла жена, заједно са осталим покућством продала; Арабелина пријатељица Ени такође не препознаје Џуда према фотографији. Могли бисмо то протумачити различитошћу друштвених очекивања од њега и од Сју, а могли бисмо, а касније ћемо то и покушати, Џудову „неуоквиреност“ приписати неуспелој припадности. Сам писац (а касније и критика) уоквирио 
је Џуда као младића „koji nije mogao da ode na Oksford“" неког ко није успео, ко није пронашао место за себе. Овом одричном дефиницијом могли бисмо напослетку описати и цео роман.

Како Елизабет Лангланд (Langland 2002: 12) каже, књижевна критика је карактерисала Сју Брајдхед и као детињасту, и као себичну, и мазохистичну и нарцисоидну и фригидну, а све у покушају да се објасни особина која се код ње сматра доминантном: непостојаност. Оквири у које је викторијанско друштво смешта, и којима и Џуд и приповедач у роману покушавају да је објасне, можда су једноставно неподесни за лик који већ у првим сценама свог појављивања показује комплексност и неухватљивост: радила је у црквеном предузећу, у чијим просторијама је и становала, те је кришом од газдарице читала Гибоново „Опадање и пропаст Римског царства“ и купила две фигурице Венере и Аполона, страсно пркосећи обредној атмосфери цркве Светог Силаса, чија је верна посетитељка била њена газдарица. Оно што сазнајемо о Сју махом је Џудово мишљење: „(...) - ti duše, ti bestjelesni stvore, ti draga, slatka, izazovna prikazo, koja gotovo i nisi od krvi i mesa, tako da kad stavim svoje ruke oko tebe, gotovo očekujem da će mi proći kroz tebe kao kroz zrak!“ (Hardi 1964: 234-235) Hapaтор Џудове и Сјуине повести често карактерише Сју као неког ко има „чудну двоструку природу“ (Hardi 1964: 199), „logiku izvanredno kompliciranu“ (Hardi 1964: 208) и која је „ро svojoj naravi i instinktu potpuno neprikladna da udovolji uvjetima bračne veze s Phillotsonom, a možda i s bilo kojim drugim muškarcem" (Hardi 1964: 209). Ако приповедачеву и Џудову оцену Сју узмемо као тачну, оквири у којима је друштво и његови актери желе видети, морали су бити изванредно мучни за особу таквог сензибилитета. Ево неколико ситуација у роману у којима се виде друштвена очекивања, почев од доба када је била девојчица, па до узраста жене и мајке:

Sjećam se, jednog je dana hodala po ribnjaku. Skinula je cipele i čarape, a suknju uzdigla iznad koljena, a kada sam joj ja viknula neka se stidi, odgovorila mi je: 'Makni se, tetkice! To nije prizor za pristojne oči!'. (...) Znate, nije baš bila sasvim poput dječaka, ali je mogla načiniti koješta što bi, obično, samo dječaci radili. (Hardi 1964: 105)

Наведени пример говори само о формалном кршењу одређених норми женског стида, које почивају на мантри о жени као нежном створењу, сличном безазленом детету. Наредни пример говори о софистициранијој огради, о забрани неписаној, али беспоговорно примењиваној - остајање у оквирима своје класе, без жеље и могућности преласка у неку другу. Тај подтекст читамо у речима жене која је неговала Џудову тетку, а која описује Сју као школарку која, најмања од свих, на подијуму сеоске школе рецитује Поовог Гаврана. Она о томе говори с чуђењем и антипатијом, говорећи да се Сjy „za

1F. E. Hardy, The Early Life of Thomas Hardy, New York: Macmillan, 1928, p. 272 (prim. aut.). 
vreme nastupa mrgodila i tragično zurila unaokolo i govorila praznom zraku kao da je tamo doista i stajalo živo stvorenje.“ (Hardi 1964: 106) Тетка се придружује коментару: „’'Ona bi odvratnog strvinara prikazala tako živo', objašnjavala je nevoljko bolesna žena, 'stojeći tamo u svojoj haljinici s pojasom da si ga gotovo mogao vidjeti pred svojim očima'“. (Hardi 1964: 106) Страсно, изражајно рецитовање не приличи девојчици у примерно уштирканој хаљиници, јер оно подразумева разумевање изговореног на нивоу много вишем од прописаних потреба, нивоу који захтева неуштирканост расуђивања. Наклоњеност књигама предмет је дубоке забринутости за будућност особе која је гаји, а у роману се у више наврата с подсмехом или отвореним презиром говори о „лудилу за књигама“, што због жалосног незнања, што због сасвим јасног разумевања последица стремљења ка вишим циљевима по неког ко је потекао из нижих слојева друштва. С обзиром на Сјуин пол, „лудило за књигама“ добија додатно злослутну димензију, јер представља претњу моделу женске субмисивности који би Сју требало да усвоји.

Немилосрдни, ускогруди систем вредности, који се врло сликовито одражава у казни за Сју, када се не врати на време у зграду Учитељске школе, чини да је у коначном ишоду важнији углед школе него потенцијално изгубљен живот ученице, важније је било одржати привид пристојности него шватити суштину догађаја и његове узроке и последице:

Kada su sišle u prizemlje, vidjele su da nije došla za njima u blagovaonicu za doručak, i onda su saznale da je strogo ukorena i da joj je naređeno da tjedan dana provede u samici, da tamo bude zatvorena, da joj se onamo donosi hrana i tamo da uči. (...) Upraviteljica je bila izvan sebe od straha ne toliko zbog eventualne smrti Suzanine koliko zbog eventualnih članaka u svim novinama, koji će u pojedinostima raspravljati o tom događaju, i to će, uz onu prošlogodišnju sablazan, kroz mnogo budućih mjeseci stvoriti koledžu nepoželjnu popularnost. (Hardi 1964: 133-134)

То јесте била школа за будуће учитељице, али требало би погледати ширу слику васпитања и образовања девојчица и девојака, која показује сву апсурдност односа циља и средства. Младе девојке и супруге држане су у стању блаженог незнања о телесним нагонима, учене су да праве даме морају бити крхке, беспомоћне, да се у свему ослањају на мушкарце, да им је задатак да се удају и да рађају децу. И ту долазимо до контрадикторности: предбрачна честитост и невиност није смела бити доведена у питање, гвоздена дисциплина је била гарант за то, као и избегавање било каквог разговора о питањима пути, а, с друге стране, комплетан одгој женског детета био је усмерен ка уметности завођења, како то каже Мери Вулстонкрафт (Wollstonecraft 2014). Дакле, са циљем што повољније удаје, млада девојка учи како да привуче подобног мушкарца, при том немајући 
и не смевши имати увида у брачне неминовности, учи да бесполно, под страшном претњом последица губитка невиности, смицалицама управо свог пола, улови пожељног мужа. За Сју, међутим, сва та уобичајена средства, жалосно названа „женским оружјем“, представљају управо супротност у односу на оно како она доживљава себе и какав би живот желела да изгради за себе: „Јa te možda ne volim kao druge žene. Ali biti s tobom za me je užitak izvanredno profinjene vrste, i ne želim ići dalje i izvrći ga opasnosti - pokušavam da ga pojačam!“ (Hardi 1964: 230) Сју је овде више на трагу Лоренсовог Руперта Беркина, него било које хероине из енглеске књижевности, тражећи врхунско интелектуално задовољство, које може али и не мора бити допуњено телесном повезаношћу. Такође, она одбија да се осећа угроженом и постиђеном у друштву мушкараца, она раскринкава илузију о жени као невином плену, одбацујући лажни стид као празну љуштуру и дајући предност вишем моралу, моралу природе и стварности, који није окован друштвеним стегама:

Ne bojim se muškaraca kao takvih, ni njihovih knjiga. Družila sam se $s$ njima - pogotovu s jednim ili dvojicom - gotovo kao da sam i sama muškarac. Hoću da kažem, nisam se u njihovom društvu osjećala onako kako su učili većinu žena da se osjećaju - da se čuvaju napada na svoju krepost. Jer nijedan prosječan muškarac - osim ako nije pohotni divljak - neće ni danju ni noću, ni kod kuće ni vani, dosađivati ženi ako mu ne da povoda. Dok ona jednim pogledom ne kaže 'Dođi', on će se uvijek bojati. (Hardi 1964: 139)

Џејн Томас (Thomas 2007) објашњава Сузанину жељу за „ужитком профињене врсте“ у вези са Џудом, њеним хеленизмом, односно уранијским виђењем везе између двоје људи. Томасова је овде на трагу једног ширег концепта, концепта неоплатонистичког обожавања мушке лепоте, који ћемо довести у везу са односом Џуда и Сју касније. Сју резигнирано каже:

A što se tiče toga da nas dvoje idemo zajedno kao što smo dosada išli, tako nekako prijateljski, to bi nam ljudi oko nas onemogućili. Njihovo je gledanje na odnos između muškarca i žene ograničeno, kako to dokazuje moje isključenje iz škole. Njihova filozofija priznaje samo odnose koji se temelje na životinjskoj želji. Široko polje jake povezanosti, gdje želja igra samo sekundarnu ulogu, to oni ne priznaju - ulogu - tko je to bio? - ulogu Venere Uranije. (Hardi 1964: 159)

Овде је Сју покушала да објасни своје становиште и оно у шта је дубоко веровала, а то је могућност односа са мушкарцем у виду другарства, неоптерећеног телесном жељом и свиме оним што она носи са собом, укључујући и брачне споне. Друштво и његов поредак, међутим, неосетљиво је на фине нијансе мушко-женских одноca, као год и односа међу људима уопште. Друштвене конвенције не препознају безгрешну, интелектуалну везу мушкарца и жене, она једноставно мора бити црна (ванбрачна, дакле сексуална, тиме и за- 
брањена), или бела (брачна, дакле дозвољена). Брачни завети гарантују испуњење брачних дужности, а главне дужности у том смислу подразумевају женину послушност и продужење врсте, озакоњеним сексуалним аспектом међусобних односа. Као Филотсонова супруга, Сју сама доноси болно тачну оцену традиционалног брака као дужности жене:

'Udata sam tek mjesec-dva', nastavi ona i dalje nagnuta nad stolom, govoreći u svoje ruke. 'A kaže se da žena nakon pet-šest godina lako i ravnodušno privikne na ono od čega se u prvim danima braka sustezala. Ali to je isto kao kad bi se reklo da amputacija ruke ili noge nije nikakva nesreća jer se čovjek s vremenom lako privikne na to da upotrebljava drvenu nogu ili ruku!' (Hardi 1964: 202-203)

Као последњи пример друштвених очекивања од жене, навешћемо ситуацију у којој су се невенчани супружници нашли при тражењу стана у Крајстминстеру, пре трагедије са децом: ниједан станодавац није желео да им изда стан, видевши их покисле и уморне, са троје деце и једним на путу, у вечерњим сатима. Ево како реагује супруг несуђене газдарице, када сазна да Сју и Џуд нису венчани:

On podiže glas u iznenadnom gnjevu. 'A kome je potrebna ovdje takva žena? A možda će i roditi ovdje!... Osim toga, nisam li ti rekao da ne želim imati u kući djecu? Dao sam svježe obojiti predsoblje i stubište, pa da mi oni lupaju po tome nogama! Moralo ti je biti jasno da s njima nije sve kako treba kad su tako došli. Uzmeš cijelu obitelj, a ja rekao sam ti da hoću neoženjenog muškarca.' (Hardi 1964: 319)

Та прилично неутрална оцена „да са њима није све како треба“ говори пуно о поједностављеном друштвеном оквиру у који би се свака јединка морала уклопити, јер, са припадницима друштва мора или да све буде како треба или да не буде. У потоњем случају, неминовно је зазирање и, најчешће, одбацивање. Сју, са свим својим душевним финесама, била је предодређена да из оквира искаче. Како је Џуд то окарактерисао, „kad nam je duh bio jasan, a naša ljubav prema istini neustrašiva - vrijeme nije bilo sazrelo za nas“. (Hardi 1964: 387)

Колико год Сју била неприлагођена, било томе узрок њено необично детињство или породично наслеђе у које се стално упире прстом, у пару са Џудом она постаје претња викторијанском поретку, јер, попут Кетрин и Хитклифа из Орканских висова, и њих двоје стапају своје идентитете и пренебрегавају границе рода, иако на другачији начин. Приповедач у роману каже да „to potpuno uzajamno razumijevanje, u kojem je svaki pogled i pokret bio isto tako djelotvoran za prenošenje misli između njih dvoje kao i same riječi, činilo je da su bili kao dva dijela jedne jedine cjeline“. (Hardi 1964: 279) Овде морамо да поменемо открића до којих долази Ли Гарднер (Gardner) у тези The Expendable Victorian: A Girardian Approach to Female Sacrifice in the 
19th Century British Novel (2011), где примењује тврдње Ренеа Жирара (Girard 1990) о нарушеној друштвеној равнотежи брисањем граница задатих категорија, и механизму жртвене кризе који се неминовно покреће услед тога. Наиме, према учењу Ренеа Жирара које је изнео у књизи Насиле и светио (1990), миметичка жеља подразумева ситуацију када особа одбацује своје стварне жеље да би подражавала жеље неког другог. У том смислу, жељено је објекай, особа која се подражава због објекта је моgел, а подражавалац је субјекай. Оваква ситуација неизбежно узрокује напетост, љубомору и насиље: „Dve želje koje konvergiraju istom predmetu jedna drugoj predstavljaju prepreku. Svaki mimezis koji se odnosi na želju, automatski se završava sukobom“. (Žirar 1990: 157) Жирар даље тврди да је могуће несметано регулисање таквог друштва када су појединци сврстани у одређене категорије и хијерархијске структуре. На основу тога закључујемо да је главна претња постојећем друштву нестанак разлика, а управо је то матрица по којој се Џуд и Сузана, у већој или мањој мери, крећу кроз живот.

С обзиром на то да Џуд и Сју из различитих побуда учествују у механизму миметичке жеље, најпре морамо да установимо узроке који их нагоне ка таквим тежњама, а онда и ток механизма, као и сам његов ишод. Наиме, Џуд је особа у суштини без идентитета, дечак који је у место у којем одраста, Меригрин, стигао жељно ишчекиван колико и каква дрвена наплавина на негостољубиво копно. После злехуде смрти мајке и оца, Џуд кров над главом (и заиста само то) налази код тетке Друсиле која, можда и ненамерно, али крајње неосетљиво, не пропушта прилику да му стави до знања да „kamo sreće da je dragi Bog i tebe uzeo, zajedno s tvojom majkom i ocem, jadni, beskorisni dječače“. (Hardi 1964: 11) Ли Гарднер (2011) сматра да хладноћа његове тетке доприноси његовом отуђењу од заједнице у којој окрутном игром случаја живи, и да је он једноставно принуђен да трага за нечим или неким са чим ће се идентификовати. Он детињство практично и нема, ишао је само у вечерњу школу код господина Филотсона, јер мора да надничи, да би тетки надокнадио трошкове свог издржавања, нема времена за игру са вршњацима. О Сјуином детињству, с друге стране, не знамо много, али оно мало цртица што знамо индикативно је за неке касније закључке. На основу онога што смо раније навели о Сјуином школовању, затим сведочењу тетке Друсиле, верујемо намерно преувеличаном у сврху одвраћања Џуда од намере да се зближи са својом рођаком („Nju je njezin otac odgojio da mrzi porodicu svoje majke, i ona će s prezirom gledati na radnika kao što si ti - ona koja je postala fina gradska djevojka“. (Hardi 1964: 105)), а онда и на основу самих Сјуиних изјава које смо раније навели, закључујемо да је Сју детињство провела у другачијем миљеу него Џуд, да је имала формално образовање које је њему фалило, те да је њен доживљај учености 
због тога потпуно другачији од Џудовог. Такође, она је одрасла колико-толико у кругу породице, неоптерећена зарађивањем и мрачним породичним наслеђем.

Интересантно је да Џуд, који очајнички стреми класичном образовању, одраста у месту чији становници не држе превише до образовања, а тако су близу центра учености, док Сју у моменту упознавања са Џудом има већ подужи стаж боравка у Крајстминстеру и, можда управо због тога, већ развијену независну, интелектуалну мисао. Сам Џуд биће исто тако близу остварења својих снова о образовању, а заправо тако далеко, као што је и Меригрин географски надомак Крајстминстера, а образовно удаљен, вероватно не случајно. Потребу да се границе категорија одржавају чврстим и непропустљивим осећају и „нижа“ и „виша“ страна границе. Овако тетка Друсила одговара на питања малог Џуда:

'Gospode! Ti bi morao znati gdje je grad Christminster. Gotovo dvadeset milja odavde. Mislim, jadni dječače, da je to mjesto mnogo predobro, a da bi ti ikada imao s njime puno posla.' 'A hoće li gospodin Phillotson uvijek biti tamo?' 'Odakle ja znam?' 'Ne bih li ga ja mogao posjetiti?' 'Ne, zaboga! Nisi ovdje odrastao, jer da jesi, ne bi tako nešto pitao. Nikada nismo imali nikakva posla s ljudima iz Christminstera, niti ljudi iz Christminstera s nama.' (Hardi 1964: 16)

Када је Џуд писао управницима колеџа, добио је одговор само једног од њих и то са саветом да ће „imati mnogo bolje izglede u uspjeh u životu ako ostane(te) u svom djelokrugu i prione(te) uz svoj zanat nego da se laća(te) bilo čega drugoga“. (Hardi 1964: 111) Овај савет је колико користан и здраворазумски, што ће се видети у трагичној радњи романа, толико и упозорење старијег и искуснијег, младој, „усијаној“ глави, која наивно и арогантно верује у илузију могућности брисања граница које су вековима бољи од њега формирали и учвршћивали. Та узајамност близине и даљине у Џудовом животу није само физичка, него и духовна и метафоричка. Најочигледнији пример за то је чињеница да цео свој одрасли живот ради на зидинама Крајстминстера, без икакве шансе да једном и уђе унутар неког од колеџа у том граду. Представу образовања као „забрањеног града“ у Неславном Џуду потврђују и социолошка истраживања о којима говори Ентони Гиденс (Giddens), наводећи њихове недвосмислене резултате: „Obrazovanje mnogo jače ispoljava tendenciju da izrazi i potencira postojeće nejednakosti nego da takvo stanje menja“. (Gidens 1998: 263) Џуду је немогуће проћи до унутрашњости оквира, конвенције и живот држе га на маргинама, изван оквира, док Сју конвенционални оквири држе заточену изнутра и не дају јој да из њих изађе. Потом, пре првог венчања Сју и Филотсона, Џуд и она ходају уз црквену лађу према олтару, у бизарном опонашању венчаног чина. Читава сцена одговара самој церемонији венчања, само што Џуд није младожења. Поново је на маргини дешавања, присутан, а болно одсу- 
тан из кључних догађаја. На самом венчању, Џуд и дословно предаје младу, предаје своју љубав неком другом, на законито поседовање, баш као што место на колеџу мора да уступи „милионерским синовима“, како то каже Сју. Чак и веза са Арабелом има те елементе близу, а далеко: по њеном одласку у Аустралију Џуд је и даље везан, она јесте географски хиљадама километара далеко, али је чин венчања неизбрисив све до његовог званичног прекида.

Занимљиво је да судбоносна повезаност Џуда и Сју није нешто што се родило у тренутку, него је томе претходио процес личног мењања, превашодно Џудовог. Он је, осим своје намере да уђе на колеџ, непримерене младићу из радничке класе, заправо потпуно конвенционалан: на Арабелине дражи, за коју приповедач каже да je „potpuna, čvrsta ženka - ni više, ni manje“ (Hardi 1964: 36), oн peaгује као и сваки просечан мушкарац, те иако неискусан у љубавним подвизима, прихвата прилично спретно Арабелину игру. Већ самим питањем да ли да јој бачени нерастов уд (којим су га погодиле Арабела и њене другарице) добаци назад или да се она попне на брвно и узме га од њега, показује да она јесте прва пустила љубавни зов, али и да је и он спреман да на њега одговори:

Neizrečeni zov, kojim žena zove muškarca, i što ga je Arabelina pojava potpuno jasno izrekla, zadržala je Judea na tom mjestu usprkos njegovoj nameri - gotovo usprkos njegovoj volji, i to na način koji je bio njegovu iskustvu nepoznat. (...) Ispitujući mu se pogled sada spustio s njenih očiju na usta, odatle na grudi i na njene punašne gole ruke, pocrvenjele od hladnoće vode a čvrste poput mramora. (Hardi 1964: 37-38)

Брак са Арабелом сведочи о томе да су викторијанске вредности ипак превагнуле у одсудним моментима - када му Арабела саопштава да је у другом стању његова реакција је потпуно конвенционална: „'Znaš da zasada nemam gotovo nikakve zarade. Možda sam morao misliti na to prije... Ali naravno, ako je tome tako, moramo se oženiti! Što misliš da bi drugo i pomislio da učinim? (...) Svakako ćemo se oženiti. Moramo!'“ (Нardi 1964: 53) Иако се овај брак практично, ако не званично, завршава Арабелиним одласком у Аустралију, и након тог искуства Џуд задржава викторијанску родну идеологију. Доказ томе видимо у његовом доживљају Сју, који се не разликује много од доживљаја Арабеле, иако је Сју готово потпуна супротност „чврстој женки“ каква је Арабела. Наиме, у првим данима свог боравка у Крајстминстеру Џуд посматра Сју и одмах осећа сексуалну привлачност, баш као и према Арабели: „Bila je tako dražesna da mu se činilo nemogućim da bi pripadala njemu“. (Hardi 1964: 83) И касније, у периоду њеног брака са Филотсоном, и када Џуд и она заснују своју заједницу, увек ће, без обзира на промене кроз које ће проћи, Џуд осећати онај импулс (за који можемо рећи и да је урођен и да је научен) родних представа, који ће му отежати прилагођавање Сјуи- 
ним захтевима. Пре свега, Џуд је посматра, дакле, поставља себе у активни положај у односу на њу, а тај положај појачава тиме што не одаје одмах да је позна и не признаје да је ожењен када му се за то укаже неколико прилика. Даље, он и несвесно размишља о њој као о објекту освајања: „Osjećao je da bi mogao biti prilično siguran u svoju pobjedu kad bi između Phillotsona i njega došlo do natjecanja tko će je od njih dvojice osvojiti." (Hardi 1964: 147) Класичан мушки нагон борбе, победе и освајања, присутан и међу људима и међу животињама, као део оне „животињске жеље“, како је Сју карактерише, а тако неприкладан када је она у питању.

Сју, пак, од самог почетка пркоси викторијанским конвенцијама на плану образовања и најочигледније, на плану шватања родних улога и представа. Стечено образовање поспешује дружењем са мушкарцима и животом у заједници са студентом, од којег је, како сама каже, научила много тога што би јој као жени било недоступно у викторијанском образовном систему. У овоме се крије и преузимање улоге која би традиционално требало да припадне мушкарцу: Сју самостално одлучује како ће изгледати њихов суживот, тј. условљава га одсуством телесне везе. Студент својевољно пристаје на њен план, не обрнуто, чиме је она практично ушла на маскулину територију. Када сагледамо обе стране једначине, видимо да Сју, женско, преузима улогу мушкарца ускраћивањем сопственог тела - дакле, нетрадиционалну улогу преузима традиционалним шватањем жене као објекта поседовања, ускраћивањем тог поседовања. Овде је Сју прешла опасну границу родних разлика и постала претња викторијанском систему, замућујући категорије рода и отелотворећи једну врсту чудовишног двојника унутар саме себе. Исту стратегију она примењује у браку са Филотсоном, где иако по људским и божанским законима припада свом мужу, она оспорава ту припадност зазирући од телесног контакта с њим, те брак остаје неконзумиран. Са Џудом, који је чак у тренутку очајања назива намигушом, ситуација је обрнута: она добровољно одлази код њега, наговештавајући сексуалну жељу, али ускраћује му своје тело све док се у њиховим животима не појави Арабела. Оваквим искривљењем мушко-женских разлика Сју осигурава себи испуњење потребе за знањем (преко Филотсона) и потребе за препознавањем као интелектуалног бића (преко Џуда). На овај начин она несвесно обмањује, али се и самообмањује, страсно верујући у илузију коју је креирала. Истовремено, она постаје главна претња друштвеној равнотежи, те је њен пут ка улози жртве зацртан.

Путање Џуда и Сју до жртвеног ритуала разликују се у смеровима. Док Џуд показује прихватање основних викторијанских вредности по питању мушко-женских односа, а мења се под утицајем Сју и постаје заговорник њених идеја, Сју најпре пркоси друштвеном поретку, да би касније наметнула себи женски идеал којем се током 
читавог романа одупирала. Што се поистовећења тиче, Џуд и Сју постају чудовишни двојници у жираровском механизму миметичке жеље, иако су то на мање очигледан начин у односу на Кетрин и Хитклифа, то јест, у овом роману се мање инсистира на једној души у два тела, него што је то случај у Орканским висовима, али је зато истакнута снажна идентификација Џуда са Крајстминстером, готово као са особом, и Сју са карактеристикама тзв. „нове жене“, према којима она сматра да мора да прижељкује целибат, као доказ своје интелектуалности и независности. Жирар каже: „Čudovišni dvojnik se javlja na onim mestima gde su se u prethodnim nalazili 'drugi' i 'ja', razdvojeni oscilirajućom razlikom“. (1990: 175) Наговештај сигурне несреће налази се управо у овим самообманама, илузијама интегритета. Ли Гарднер (2011) верује да је Џудово толерисање Сјуине сексуалне апстиненције наставак проблема, јер он у механизму миметичке жеље узима Сју за модел, што аутоматски значи да он прижељкује нешто што није оригинално његова жеља.

Задржаћемо се на Сјуином преузимању улоге мушкарца, према родним стереотипима. Поменули смо да је још као девојчица волела игре у којима су учествовали углавном само дечаци, а кад је ушла у девојаштво зближила се са студентом који јој је омогућио читање књига којима никад, као девојка, не би имала приступ, те је уз његову помоћ, расправљајући, читајући, развила свој необичан ум. Живела је са њим петнаест месеци у једној дневној соби, попут другара, цимера, у илузији могућности одржања таквог стања, поставивши своја правила о платонском односу између њих, елиминишући на тај начин могућност успостављања брачног односа, стуба викторијанске шеме односа, што угрожава систем родних стереотипа. Ни Џуду она не признаје да га воли, само му у једном писму (пре него што сазна да је он ожењен) дозвољава да је воли: „Bio si tako dobar i nježan prema meni da sam, kad sam te izgubila iz vida, osjetila koliko sam bila okrutna i nezahvalna da sam ti to rekla, i sve od onoga časa me to progoni. Smiješ me ljubiti, Jude, ako hoćeš. Ništa se ne protivim tome, i nikada ti više neću reći da me ne smiješ ljubiti“. (Hardi 1964: 147)

Додајмо овоме и једну Сјуину изјаву, која често остане незапажена. Наиме, када после бега из Учитељске школе прегази реку и затражи уточиште код Џуда, она признаје да је, упознавши га, имала необичан план за њега: „Ali ja sam zbilja željela i čeznula za tim da oplemenim neke ljude za visoke ciljeve; i kad sam vidjela tebe, i saznala da mi želiš biti drug, ja sam - da li da priznam? - pomislila sam da bi ti mogao biti taj čovjek“. (Hardi 1964: 144-145). Сју своју родну двострукост овом идејом носи корак даље - готово да би она и Џуд могли бити и у улози учитеља и следбеника, попут старогрчких примера. Дакле, не само да она преузима мушки примат у смислу родних односа у заједници, него се лаћа и улоге подучаваоца, некога ко ће Џуда водити и у питањима науковања и у питањима животних ставова, 
што је, опет, најчешће улога за мушкарца, и то старијег, искуснијег. Интересантно је да је она у том тренутку неко ко је практично избачен из традиционалног система образовања, што је још једна назнака да друштвени механизам осећа њену Другост и од ње се брани. Другарство о којем она говори Џуд доживљава као мучење:

On okrenu pogled jer mu je ta njena bespolna nježnost zadavala previše muke. Je li to ono što je slomilo srce jadnom piscu uvodnika? I treba li da on bude slijedeći?... Ali Sue je tako mila!... Kad bi samo mogao da zaboravi na njezin spol, kao što ona, čini se, tako lako zaboravlja na njegov, kakav li bi drug mogla biti! (Hardi 1964: 145)

Сју, заправо, нимало не заборавља ни на чији пол, него свесно користи друштвена очекивања од жене за свој циљ остваривања целибата (наговештавајући могуће телесно задовољење страсти и ускраћивањем истих), а у сврху интелектуалних добитака, што је, опет, у сврху њене миметичке жеље за концептом „нове жене“. Ли Гарднер (2011) с правом закључује да миметички троугао у којем су се нашли Џуд и Сју узрокује напетост у њиховом односу од самог почетка, јер је њихов однос платонски у већем делу романа, те да их њено спречавање сексуалног изражавања њихове везе заправо спречава да остваре истинску срећу. Ситуација се мења кад се Арабела врати из Аустралије, односно мења се смер Сјуине миметичке жеље. До тада, концепт „нове жене“ било је оно чему је тежила, а сада, суочена са „потпуном, чврстом женком“ и потенцијалном Џудовом реакцијом на њу, Сју мења модел, па је њена жеља сада заправо Арабелина сексуална жеља за Џудом. Њихов дотадашњи платонски однос, којим се поносила, у складу са новим моделом миметичке жеље, мора бити замењен приземнијим: „Рa dobro, ako moram, moram. Ako ti hoćeš da bude tako, ja pristajem! Bit ću tvoja. Samo nisam to namjeravala! A nisam se htjela ni ponovo vjenčati!... Ali da - pristajem, pristajem!" (Hardi 1964: 254) Она иде и даље, управо у складу са приповедачевим опаскама о њеним покајничким нагонима („Nije bilo granice čudnim i nepotrebnim činima pokajanja što bi ih Sue ponizno izvršila kad je bila u pokajničkom raspoloženju“ (Hardi 1964: 255)), те „Judeu je dopustila da je poljubi slobodno, i uzvraćala mu poljupce kao nikada prije“. (Харди 1964: 255) Она не само да се труди да опонаша модел, него и да га превазиђе, па макар и у изгледу, јер је, посетивши Арабелу наредног јутра, видела њено не баш ласкаво издање, нарочито у поређењу са сопственом „svježom dražesti“ (Hardi 1964: 256). Ли Гарднер (2011) запажа да Сјуино мењање модела доводи не само до напетости између ова три лика, него и до недостатка разлика између стварних жеља, захтева друштва и жеља других. Када Сју и Џуд најзад доживе и телесно испуњење своје љубави, тј. када Сју попусти под притиском новог модела, Џудова миметичка жеља за платонском везом нестаје, али родна равнотежа још увек није успостављена, јер Сју и даље не 
пристаје на брак, а чини се и да је Џуд све сумњичавији у вези са идејом да је у чину венчања „Vrhunac njihove ljubavne sreće“ (Hardi 1964: 272). Упркос ванбрачној вези, њихова ментална унија снажна је и, као што смо већ навели, они делују као једна душа у два тела, што спознаје и сам Филотсон: „..., pale su mi u oči ove dvije činjenice; izvanredna simpatija ili sličnost između njih dvoje. (...) Oni kao da su jedna te ista osoba u dva tijela!“ (Hardi 1964: 219) Блискост и разумевање који владају у њиховом микросвету не нарушава ни изненадни долазак Џудовог и Арабелиног сина, напротив, после прве забринутости, он је прихваћен с нежним разумевањем и ганутошћу. Сју каже: „Uс̌init ću sve što budem mogla da mu budem majka, a nekako ćemo ga moći uzdržavati. (...) Možeš me zvati majkom, ako to želišs, jadno moje drago“ (Hardi 1964: 263, 266). Џуд већ кује планове за будућност Малог старца: „Nego, Sue, ljubavi, imam jednu ideju! Uzgajat ćemo ga i poučavati s ciljem da dođe na sveučilište. Ono što nisam kod sebe mogao postići, možda ću moći provesti kroz njega“. (Hardi 1964: 266) Харди даље слика готово прерафаелитску слику идиле двоје младих са дететом:

Sue, u svojoj novoj ljetnoj haljini, gipka i laka poput ptice, s malim palcem pruženim uz držak bijelog pamučnog suncobrana, hodala je gotovo kao da se i ne dotiče tla i kao da bi je umjereno jak dašak vjetra otpuhnuo preko živice u susjedno polje. Jude, u svom svijetlosivom prazničkom odijelu, doista se ponosio što je u njenu društvu, jednako toliko zbog njene vanjske privlačljivosti koliko i zbog njenih srdačnih riječi i postupaka. (Hardi 1964: 279)

Наглашава се снажна повезаност између Џуда и Сју, која чини да разлике међу њима, толико потребне класификаторском друштву, буду све мање видљиве: „То potpuno uzajamno razumijevanje, u kome je svaki pogled i pokret bio isto tako djelotvoran za prenošenje misli između njih dvoje kao i same riječi, činilo je da su bili kao dva dijela jedne jedine cjeline“ (Hardi 1964: 279). И Арабела, на свој начин и у складу са својим (и наравно, општеприхваћеним) шватањима мушко-женских односа и брака, примећује необичну блискост ово двоје: „'Kako li ga se drži!', reče Arabela. 'O ne - ne mogu vjerovati da su vjenčani, jer onda ne bi značili jedno drugome toliko.' (...) 'Očarala ga je kao da je kakva vila!', nastavi Arabela. 'Pogledaj kako pogledava na nju i zadržava svoj pogled'“". (Hardi 1964: 280) Равнодушна, али сасвим јасна и тачна оцена Џудове и Сјуине заједнице долази од стране Арабелиног мужа, Картлета: „'Čini se da se prilično vole, i da vole svoje dijete"“(Hardi 1964: 278).

Нажалост, све то, показаће се, није довољно за срећу, него је, напротив, узрок несреће. Спољна слика породице овде, зачудо, игра апсурдно двоструку улогу: обичан, незаинтересован посматрач нема разлога да у призору Џуда, Сју и Малог старца не види родитеље с дететом, док се пажљивијем посматрачу, па још ако је лично заинтересован, као што је то била Арабела, може учинити да је њихова блискост невероватна за један брачни пар. Брак и породица, 
као основе друштва, према томе искључују нешто друго основно за људску врсту: узајамну нежност и посвећеност, а остављају пословну вредност уговора. Обрнуту слику брачне идиле, овог пута сатиричне, видимо у обновљеном браку Џуда и Арабеле, када им станодавац жели отказати најам, јер су, већ сумњиви, постали сумњивији када је Арабела, под утицајем ракије, једне вечери пољубила Џуда: „On se bio spremao da im otkaže, ali je jedno veče slučajno čuo kako je oštrim riječima napala Judea, a onda mu je bacila u glavu cipelu, pa je prepoznao atmosferu običnoga braka. I tako je zaključio da mora da su vrijedni poštovanja, i više nije rekao ni riječi“ (Hardi 1964: 371-372). Џуд и Сју су, тако, непотписивањем уговора, прекршили одредбе друштвеног уговора и својом повезаношћу ван одобрених оквира осудили себе на страдање. Апсурдно је да је идиличност слике породице основ за сумњу у њену валидност, па чак и за трагичан крај. Један део композиције ове слике одиграће пресудну улогу у ритуалу жртвовања, који би требало да допринесе поновном успостављању друштвене равнотеже. Наиме, Мали старац ће деловати као спољни деструктивни елемент - с обзиром на то да је он Џудово и Арабелино дете, те је једини од троје деце рођен у браку, деловаће као епитомизација друштва које, најпре константним немилосрдним подсећањем на кршење правила, а онда и конкретним чином, елиминише непожељне чланове тог друштва. Мали старац жртвује себе и друго двоје деце: „Učinio sam to jer nas je previše“ (Hardi 1964: 323). Мали старац је и сведочанство законски признатог брака, као и његовог слома, он је и подсетник да су друго двоје деце донети на свет ван брачних оквира, према томе, друштвено неприхватљиви и невидљиви. С обзиром на то да се од тренутка смрти троје деце у потпуности мења живот Џуда и Сју, а сама Сју поново мења смер свог миметичког механизма, Мали старац је у том смислу проводник путем којег су друштвене конвенције на силу продрле у њихову заједницу. Суровост постојања Малог старца и далекосежне последице одрастања са сазнањем и убеђењем да „bi bilo bolje ne biti na svijetu nego živjeti...” (Hardi 1964: 320) у супротности су са Џудовим и Сјуиним занесењачким идеализмом. Мишел Фобер (Faubert 2002) занимљиво запажа да је Мали старац и реалистичан и симболичан лик. Од момента када се први пут појави у роману, „On kao da je nijemo govorio, (...) svojim okruglim očima: 'Svaki smijeh je posledica nerazumijevanja. Ako se ispravno gleda, nema smiješne stvari pod suncem"' (Hardi 1964: 263). Његов чин саможртвовања и жртвовања, ма колико шокантан био, изазива очекивану последицу, према речима Мишел Фобер, а то је потпуни распад Џудовог и Сјуиног заједничког живота. У том смислу, Мали старац функционише и као продужена рука друштвене неминовности, а у складу са именом којим га зову (у оригиналу: Little Father Time ${ }^{2}$ ), симболично представља учинак времена на не-

2 Time, engl. $=$ vreme. 
прилагођени живот, какав су Џуд и Сју одабрали. Како је Сју једном изјавила да друштво не би дозволило да њихово дружење, без озваничења односа, траје дуго, Мали старац у својој симболичној варијанти то и доказује. Он је и заиста мали старац, „прерано сазрео” (Hardi 1964: 267), а истовремено је и млад, јер је тек дечак, тако да он представља време уопште - и прошлост, и будућност и садашњост. Тим својством симболично потврђује неумитност свог деловања, а практично, крајњу пресуду друштвених околности. Сју тога постаје свесна у свом неизмерном болу: „To što je Arabellino dijete ubilo moju djecu, to je kazna - pravednik je ubio grešnike”. (Hardi 1964: 336)

Сју тако од бесполне жене, како је називају и приповедач и Џуд, и жене која преузима конвенционалну улогу мушкарца, постаје генеричка жена, како је назива Гарднер (2011). И Џуд је сад доживљава тако, те се чини да су испуњени услови за исправљање искривљених друштвених односа и успостављање релативне равнотеже: „Оно што ја не могу разумјети, то је твоја садашња изванредна сљепоћа за твоју стару логику. Је ли то нешто што је осебујно за тебе, или је то својствено свима женама? Је ли жена уопште мисаона јединица, или само један дио којему увијек недостаје његова ћелина?"” (Hardi 1964: 337) Раздвајање чудовишних двојника потврђује сам Џуд: „’Neka se, dakle, ovoga časa zastor našeg hrama raskine na dvoje!'” (Hardi 1964: 341) Но, жртвовање се овде не завршава. Да би до краја испунила улогу идеалне жене, Сју се мора вратити Филотсону и поновити чин венчања. Уколико овде применимо теорију Џудит Батлер (Butler 2007) о перформативности рода, могли бисмо овај Сузанин поступак разумети као понављање поступака, ради стварања илузије трајно родно обојеног сопства. Чином поновног венчања Сју постиже перформативност своје улоге - глуми суштину, конструише свој идентитет, у који и она и Филотсон, као други учесник у чину, а и само друштво верују, тачније, којег, према Батлеровој (2007), одигравају на начин као да верују у њега. Батлерова каже да се родна трансформација може наћи „u nasumičnim odnosima između takvih činova, u mogućnosti da ponavljanja budu različite vrste, u prekidanju ili subverzivnom ponavljanju datog stila“. 3 (Butler 2007: 520) Управо би Сузанино венчање са Џудом могло да буде то субверзивно понављање - покушај трансформације рода који се трагично завршава. Док Берман (Berman 1989) тврди да су њени поступци нездрави, Гарднерова (2011) објашњава да они јесу нездрави лично за њу, јер она поступа противно својим жељама, али доносе друштвену добробит, јер и административно раздвајају Џуда и Сју, истовремено рехабилитујући Филотсонов положај у друштву, који је изгубио својим друштвено неприхватљивим давањем слободе својој законској супрузи. Сада, Филотсон, по савету свог пријатеља Гилингама, не пушта Сју из брачног оквира. Упркос телесној авер-

3 ["In the arbitrary relation between such acts, in the possibility of a different sort of repeating, in the breaking or subversive repetition of that style." Prevod: N. G.] 
зији према Филотсону, Сју му се овог пута не опире, те му се предаје спремније него Џуду, изгубивши тако власт над својим телом, у замену за живот, након механизма жртвовања. Она је сада у потпуности остварила викторијански идеал жене, а Џуд је ту још само да подсети на њену стварну жељу за заједницом из љубави и интелектуалним партнерством. Поновљени обред венчања са Филотсоном само је једно у низу саможртвовања, које је Сју некада звала пристанком „da se žena dobrovoljno žrtvuje na oltaru svojih principa“ (Hardi 1964: 355). Приповедач за Сју у тим моментима каже да је „pročišćena, umorna od svijeta, ispunjena grižnjom savjesti, s tijelom izmučenim od napetosti živaca, činila se manjom nego prije, premda ni u danima najčvršćeg zdravlja nije bila krupna žena“. (Hardi 1964: 355) Ово је опис сломљене жене, дубоко рањене страшном трагедијом и управо зато склоне да потражи искупљење у безусловној предаји свега што је представљало њен идентитет. Баш као што је ревносно пркосила очекивањима друштва, с подсмехом слушала Џудове занесене хвалоспеве Крајстминстеру и становницима колеџа, једнако ревносно је сад себе кажњавала због тога и, како је рекла, морала је испити пехар до дна. Када Џуд дође да је посети код Филотсона, она му пружа не баш убедљив отпор, те у тренутку попуштања миметичког механизма она потрчи према њему и, „s ustima na njegovim” (Hardi 1964: 376), очајнички признаје: „'Volim! Ti to i predobro znaš!... Ali ja to ne smijem činiti! Ne smijem ti uzvraćati poljupce kako bih to htjela!"' (Hardi 1964: 376) Баш као и Кетрин из Орканских висова, када после дужег боравка код Линтонових, дотерана и углађена, полети Хитклифу, загрли га и изљуби. Када Џуд спомене дечицу, Сју се тргне и враћа у колосек своје миметичке жеље: „’Ne smijem to učiniti - ne mogu!' (...) 'Ali sada sam opet svoj gospodar. Nemoj ići za mnom - nemoj me gledati! Ostavi me, smiluj mi se!"” (Hardi 1964: 376-377) Молећи за милост, одиграва и последњи чин у представи Кућног анђела. У улози крхке жене, јединој коју јој викторијанско друштво допушта, вероватно се наставља њена несрећна приповест. Ођек и предосећање тога налазимо у Арабелиним речима на крају романа: „’'Otkad je otišla iz njegova naručja, ona nije našla mira, niti će ga naći, dok i ona ne bude ono što je on sada!"” (Hardi 1964: 395) Њен мир је овде неважан фактор, сматра Гарднерова (2011) - једини мир који је битан је друштвени мир, заправо поново само његова илузија, а то је постигнуто. Доказ томе читамо и у речима госпође Едлин, старе пријатељице Џудове тетке: „’ako je ostarjela otkad ste je posljednji put videli. Ona je sada potpuno utučena, stara žena. Sve je to zbog muža - ne može da ga podnese, čak ni sada!'” (Hardi 1964: 394) Сју је једноставно поделила судбину толиких жена деветнаестог века, судбину против које се борила кроз цео роман. Када Арабела каже да можда Џуду не би више ни било стало до ње, да ју је видео тако пропалу, она заправо у својој саможивој реалности даје конкретан показатељ колико је друштво за које Џуд и Сју никако нису били подобни формалистичко и површно. 
Џуд, с друге стране, као и Хитклиф, мора умрети, као последња преостала препрека за враћање равнотеже. Сада када је Сју прихватила улогу коју је одбијала цео живот, Џуд је постао већи поборник природе њихове заједнице и њених пређашњих погледа на свет:

'Iskorijenila si iz mene i ono malo ljubavi i poštovanja što sam ga imao prema crkvi kao staroj znanici... (...) Odbacila si stare ljuske predrasuda i naučila i mene da to radim, a sada sama sebi protivuriječišs. (...) O, ti draga, tužna, nježna, najžalosnija ruševino najnadobudnijeg ljudskog intelekta koji mi je sudbina ikada dopustila da ga sretnem! Kamo je nestao tvoj prezir konvencionalnosti? Ja bih za nj bio dao ruku u vatru!' (Hardi 1964: 337-338, 376)

Он, као и његов син, одлучује да се саможртвује, швативши да је Сјуин крик: „Nemam više borbenosti u sebi, nemam više poduzetnosti. Potučena sam, potučena!“ (Hardi 1964: 329), заправо порука њему да су они од тог момента две душе у два тела, и да снага чудовишних двојника нестаје. Џудове амбиције о школовању у неком од крајстминстерских колеџа одавно су се расплинуле, та илузија није више претња, али је остало оно чему га је Сју научила, те је неопходно да он као доказ тога нестане са друштвене сцене. Поново ожењен Арабелом, он свесно убрзава своје пропадање: друштвено прихватљива веза уништава есенцију његовог бића, баш као што је то случај и са Сју. Овог пута, обележен неизмерним болом губитка и сазнања да је изгубио своју животну љубав, Џуд уопште не примећује Арабелине смицалице, равнодушност је обузела свако његово чуло, изузев страшне патње за изгубљеним делом своје душе. Телесно пропадање заједничко је и за Џуда и за Сју, с тим што Џуда додатно убијају последице некадашње болести, баш као и Кетрин у Орканским висовимa. Џудова смрт је други ритуал жртвовања у роману, а претходило му је прочишћење путем деловања воде, баш као и у Хитклифовом случају. Наиме, Џуда је у повратку са последњег сусрета са Сју ухватио страшан пљусак и шибао га је ледени североисточни ветар преко поља са којег је као дечак плашио вране за фармера Траутама. Изнемогао, већ мокар и промрзао, морао је још и да легне да се одмори, док га је киша запљускивала. Његова смрт не наступа одмах, али је баш ту, близу места где су се растали његови родитељи, близу километарског стубића на којем је давно уклесао свој животни циљ - „ONAMO J. F.“ (Hardi 1964: 69), потписана и његова смртна осуда. Оставивши иза себе путоказ којим се надао да ће се водити кроз живот, оставивши Сју као отелотворење својих илузија о образовању и љубави, оставивши своју дечачку прошлост и суморно родитељско наслеђе, још је само требало да прође поред непријатељских колеџа у Крајстминстеру, па да његово прочишћење буде потпуно, те да тако без икакве телесне снаге буде жртвован у механизму који су он и Сју покренули. У сцени свог последњег проласка кроз Крајстминстер смењују се утваре славних научника и Арабелини примитивни, али прикладни коментари: 
'Prikaze! Nema nigdje ni živa ni mrtva čovjeka, osim onoga prokletog policajca!' (...) 'Zamisli! Ovuda je nekoć hodao Pjesnik slobode, a onda veliki Proučavatelj melankolije!' 'Ne zanimaju me oni. Dosadni su mi!' 'S onog mi puteljka klima glavom Walter Raleigh - Wycliffe - Harvey - Hooker - Arnold - i čitavo mnoštvo traktarijanskih sjena...' 'Ne želim znati kako se zovu, kažem ti! Što mi je stalo do ljudi koji su umrli i nema ih više? Tako mi boga, ti si trezniji kad nešto popiješ nego kad ne piješ!' (Hardi 1964: 379)

И његово лице одражава прелазак из свесног живота у несвесни, неопходан за довршавање жртвеног ритуала: „Judeovo sablasno lice, u kiši i pod svjetlom ulične svjetiljke, doista je bilo takvo kao da vidi ljude tamo gdje nije bilo nikoga" (Hardi 1964: 379). И он, и Кетрин и Хитклиф, пред последњи чин су били у сличном стању. Кетрин је отишла у агонији пораза својих фантазија и промашених избора, Хитклиф је посустао после вишегодишњих натчовечанских настојања да освети себе и Кетрин, увидевши да је на крају сваки отпор бесмислен, обоје су пред смрт видели фантоме својих недосањаних снова, а Џуд умире уз звуке оргуља са свечаности која му је некад била звезда водиља и са пророчанским стиховима на уснама:

'Nestalo dana u koji se rodih, i noći koja reče: 'Začelo se muško dijete' ('Živio!') 'Obratio se taj dan u tamu, ne mario za nj ni Bog na nebu, nit' ga ikad svjetlost obasjala. Pusta bila ona noć; protjerala se radost iz nje.' (Živio!) 'Što ne umrijeh u utrobi materinoj? Što ne izdahnuh izlazeći iz nje?... Ja bih sad ležao i miran bih bio, spavao bih i počivao bih!' (Hardi 1964: 390)

Својеврсном самоубиству овде следи и назнака новог живота или нових односа. Кетрин је умрла рађајући ћерку, која је опет, пред Хитклифову смрт остварила везу постепено изграђену, друштвено прихватљиву, а засновану на љубави. Као бурлескни епилог Арабелиних напора да се обезбеди уз помоћ мушкарца, након Џудове смрти (па и мало пре ње), даје нам се најава њене везе са надрилекаром, која такође неће уздрмати друштвену равнотежу. Харди нам тиме наглашава да, и поред свих напора појединца, друштвени оквир на крају успе, уз веће или мање жртве, да обухвати сваког и врати под своју стегу сваку заблуделу овчицу. Сав очај и безизлаз таквог круга ођекују у Сјуином и Џудовом разговору, неко време после смрти дечице:

'Volim te, Jude', reče nježnim i molećim glasom. 'Volim te kao uvijek! Samo što te više - ne bih smjela voljeti. O, ne smijem te više voljeti!' 'S tim se ne mogu složiti.' 'Ali ja sam stvorila zaključak da nisam tvoja žena! Pripadam njemu - sakrament me je povezao s njim za cijeli život. Nema toga što bi to moglo izmjeniti." Ali sigurno je da smo ti i ja muž i žena, ako su to ikada dvoje ljudi bili na svijetu! To je bez sumnje brak kakav priroda ${ }^{4}$ želi!' 'Ali ne kakav želi $n e b o^{5}$. Na nebu je sklopljen onaj moj prvi brak i potvrđen za vječna vremena u crkvi u Melchesteru.' (Hardi 1964: 337)

4 Kurziv autora.

5 Kurziv autora. 
Та немилосрдна неумитност вечности као да је карта која се вади из рукава сваки пут када аргументи постану сувише јаки и непобитни за страну којој не одговарају. Пред њом су изгубљене душе немоћне, а Сју због ње, у свом болу, оно што је некад осећала као спољне препреке, сад осећа унутар себе: „'Ima nešto izvan nas što govori 'Ne smiješ!' Najpre je reklo 'Ne smiješ učiti!' Onda je reklo 'Ne smiješ raditi!' Sada kaže 'Ne smiješ ljubiti!'“ (Hardi 1964: 324). To је учинак оквира у које је Сју враћена насилно припитомљена, и због којих је Џудова судбина била самоуништење. Илузије о интегритету, могућностима постојања ван прописаних оквира који су и сами једна велика, али легитимна обмана, допринели су трагедији појединаца. Остаје питање коме се десило мање зло, Сузани, која је физички преживела, а духовно је потпуно мртва, или Џуду, који је физички нестао из живота, осећајући, баш као кад је био дечак, „da je njegov opstanak nepoželjan“ (Hardi 1964: 16), и који је зарад љубави затомио снове и променио веровање, а на крају остао без љубави.

\section{ЛИТЕРАТУРА}

Berman, Jeffrey. Infanticide and Object Loss in Jude the Obscure. Compromise Formations: Current Directions in Psychoanalytic Criticism. Ed. Vera J Camden. Kent: Kent State UP, 1989.

Butler, Judith. "Performative Acts and Gender Constitution: An Essay in Phenomenology and Feminist Theory". Theatre Journal, Vol. 40, No. 4. (1988): 519-531.

Crangle, Sara. "Hardy's Jude the Obscure“. The Explicator. Vol. 60, issue 1 (2001): 24-27.

Faubert, Michelle. "The Significance of Little Father Time in Thomas Hardy's Jude the Obscure." The Explicator. Vol. 60, issue 2. (2002): 76-78.

Gardner, Leigh M. The Expendable Victorian: A Girardian Approach to Female Sacrifice in the 19th Century British Novel. Michigan: Central Michigan University, 2011.

Gidens, Entoni. Sociologija. Preveo s engleskog: Đurica Krstić. Podgorica: CID, 1998.

Hardi, Tomas. Neslavni Jude. Preveli s engleskog: Grgić Berislav i Simić Novak. Zagreb: Zora, 1964.

Langland, Elizabeth. "A Perspective of One's Own: Thomas Hardy and the Elusive Sue Bridehead". Studies in the Novel. Vol. 12, No. 1. (1980): 1228.

Thomas, J. “Thomas Hardy, Jude the Obscure and 'Comradely Love“". Literature and History. Vol. 16, issue 2. (2007): 1-15.

Žirar, Rene. Nasilje i sveto. Prevela s francuskog: Svetlana Stojanović. Novi Sad: Književna zajednica Novog Sada, 1990. 
Wollstonecraft, Mary. A Vindication of the Rights of Woman. Adelaide: University of Adelaide, 2014.

Nataša Gojković

\author{
Jude Fawley and Sue Bridehead: \\ Illusions about a Life Outside the Societal Framework
}

Summary

Jude and Sue, Hardy's tragic lovers, each have dreams untypical of the society of their time. As a couple, they move outside the prescribed framework of their respective social positions, setting in motion the mechanism of events that will result in great sacrifice with the ultimate goal of restoring the social balance of gender and class categories. This paper has shown that an individual is too weak to fight the conventions of society. Both Jude and Sue aspire beyond their predestined roles and categories but are ill-equipped to endure the blows of life outside the societal framework: Jude is torn between the traditional male role and his vision of himself as a learned man, whereas Sue both intuitively and consciously crosses the gender border, dreaming of becoming "a comrade" to her emotional partner and suppressing the physical part of her character. Thus, they blur the borders which society has raised in order to keep its members within the proper limits. Once disturbed, the balance needs to be restored, so Jude and Sue become the victims of the mechanism of mimetic desire and sacrificial crisis. This paper has shown that in Jude the Obscure the conventions of society are far too strong for any individual to remain intact outside them. The sacrificial crisis which ends the agony of Jude and Sue's battle against the conventions and apparently restores the traditional balance is nothing but another illusion: Jude's physical death seems tragic, but it ends sufferings and removes the threat to the society, whereas the death of Sue's soul is utterly tragic because it represents the token of the ultimate victory of the society over an individual.

Keywords: Jude the Obscure, class, gender, illusion, self-deception, mimetic desire, sacrificial crisis 